\title{
Infantile hypophosphatasia
}

INSERM

\section{Source}

INSERM. (1999). Orphanet: an online rare disease and orphan drug data base. Infantile hypophosphatasia. ORPHA:247651

Infantile hypophosphatasia (I-HPP) is a very rare, severe form of hypophosphatasia (see this term) characterized by infantile rickets without elevated serum alkaline phosphatase (ALP) activity and a wide range of clinical manifestations due to hypomineralization. 